\title{
Clinical retrospective analysis of 70 discharged patients with the Coronavirus disease 2019 (COVID-19) in Hangzhou, Zhejiang Province
}

\author{
Zhongbao Zuo \\ Hangzhou Xixi hospital \\ Jing Wu \\ Hangzhou Xixi hospital \\ Miaochan Wang \\ Hangzhou Xixi hospital \\ Yujiao Jin \\ Hangzhou Xixi hospital \\ Wenyan Yu \\ Hangzhou Xixi hospital \\ Haiying Niu \\ Hangzhou Xixi hospital

\section{Yangjun Chen} \\ Hangzhou Xixi hospital

\section{Pengbo Liu} \\ Shenzhen Mindary Bio-Medical Electronics Co., Ltd

\section{Deyu Zeng} \\ Shenzhen Mindary Bio-Medical Electronics Co, Ltd \\ Dongming Sui \\ Hangzhou Xixi hospital \\ Zhaobin Cai \\ Hangzhou Xixi hospital \\ Aifang Xu ( $\sim 13616500869 @ 163 . c o m$ )
}

\section{Research article}

Keywords: COVID-19; SARS-CoV-2; 2019nCoV.

Posted Date: May 12th, 2020

DOI: https://doi.org/10.21203/rs.3.rs-27333/v1

License: (c) (i) This work is licensed under a Creative Commons Attribution 4.0 International License. Read Full License 


\section{Abstract}

Background Since the Coronavirus Disease 2019 (COVID-19) was first identified in Wuhan, China, caused by the Severe Acute Respiratory Syndrome Coronavirus 2 (SARS-CoV-2) pathogen, the disease has been found in many countries. Considering the lack of effective drugs and rapid spread of COVID-19, we did a clinical detailed retrospective analysis of 70 discharged patients which can help us to better determine the clinical features of the disease.

Method We collected demographic, epidemiological, clinical, laboratory, and chest computed tomographic (CT) data from patients' hospital records, the time period were from hospitalization day 1 to day 7 and hospitalization last day. The retrospective study totally included 70 COVID-19 patients.

Results The median age was 43 (IQR: 34-56) years. 41 (58.6\%) patients were female, and there were $33(47.1 \%)$ patients who were hospitalized more than 14 days. $18(25.7 \%)$ patients were residents of Wuhan or recently travelled to Wuhan, 38 (54.3\%) patients were having a close contact with the COVID-19 patients. The most common preexisting diseases were liver disease (15.7\%), hypertension (12.9\%), renal disease (8.6), lung disease (5.7\%). The time from illness onset to hospitalization was 4 (IQR: 2-7) days. The most common treatment regimen was Lopinavir/ritonavir (LPV) + Interferon alpha inhalation (IAI) + Arbidol. Compared with hospitalization day1, White blood cell count, C-reacting protein, Potassium, Aspartate aminotransferase, Lactate dehydrogenase, and Lactic acid were significantly different than hospitalization day-last. The median number of times a patients receiving chest computed tomography (CT) from day1 to day7 was 3 (IQR: 3-4). The typical chest computed tomographic images were patchy shadows and ground glass opacity.

Conclusion Currently, there are no specific antiviral therapies for COVID-19. 70 COVID-19 patients in our study responded positively to treatment during the two-week period. For those discharged patients with abnormal results, more attention is needed in the future studies to control the transmission.

\section{Background}

Since the Coronavirus Disease 2019 (COVID-19) was first identified in Wuhan, China (1), caused by Severe Acute Respiratory Syndrome Coronavirus 2 (SARS-CoV-2) (2) pathogen, the disease has been found in many countries. The World Health Organization (WHO) has declared COVID-19 in China as a public health emergency of international concern (3). By the end of February 29, 2020, there were 79,824 confirmed patients in China and 6,267 confirmed patients across 56 additional countries $(3,4)$.

In the first period of the disease, researchers (1) described the epidemiology and clinical characteristics with 41 patients from Wuhan, China, and the transmission from human to human was identified in other study (5).

Additionally, some excellent clinical researches (6-8) described the characteristics of the COVID-19 which can provide a good understanding of disease prevention and treatment. Considering the lack of effective drugs and rapid spread of COVID-19, we conducted a clinical detailed retrospective analysis of 70 patients who have been discharged after hospital stays to help us accurately understand the disease's clinical features.

\section{Method}

\section{Study design and participates}


The retrospective study was approved by the institutional ethics review board of Hangzhou Xixi Hospital. All COVID19 patients confirmed according to WHO interim guidance(9) at Hangzhou Xixi Hospital from 20, January 2020 to 28, February 2020 and then discharged from the hospital were enrolled in this study. All patients were signed with an inform consent. Hangzhou Xixi Hospital is one of the designated tertiary hospitals and is assigned by the government to treat COVID-19.

\section{Data collection}

We collected demographic, epidemiological, clinical, laboratory, and chest computed tomographic (CT) data from patients' hospital records. Collected data span from day 1 to day 7 and the last day of hospitalization. If the information was not clear or missing from the record, we directly contacted the doctor for the clarification. If some laboratory records were missing from the last day of hospitalization, we used the most recently available records; these records were no older than three days before hospitalization discharge. All the information obtained from the record was double-checked. Time from illness onset to hospitalization was defined as illness onset to the hospitalization.

Sputum and throat swab samples were collected from all patients at admission for real time polymerase chain reaction (RT-PCT) in the local CDC. Patients also received routine blood, serum biochemistry, and other respiratory pathogens such as influenza A virus, influenza B virus, respiratory syncytial virus, para influenza virus, and adenovirus. In some cases, patients were later tested for their actual need.

With the CT retrospective data, we defined 'Same' as images that show the same patterns as previous result; 'Better' as a better result compare with a previous image, such as the absorption of bilateral ground glass; 'Worse' as images that show a bad result compare with a previous image, such as the expansion of bilateral ground glass; and 'Normal' as CT images that demonstrate normal.

Before hospital discharge, patients are expected to meet the following standard: (1) Body temperature returns to normal for more than three consecutive days; (2) respiratory symptoms improve; (3) CT shows that acute exudation has significantly improved; (4) test negative for SARS-Cov-2 on two RT-PCR tests taken 24 hours apart.

\section{Statistical analysis}

We showed continuous variable as means and standard deviations (SD) if they are normally distributed or median with interquartile ranges (IQR) if they are not. We present categorical variables as count (\%). All the analyses were performed with SAS software (version 9.4) and R software (version 3.6.0). $P<0.05$ was considered as statistically significant for all tests.

\section{Results}

\section{Demographic and baseline characteristics}

This study examined 70 COVID-19 patients discharged from the hospital by the end of February, 282020 . The median age was 43 (interquartile range, IQR: 34-56) years. 2 (2.9\%) patients were 18 years and younger, 26 (37.1\%) were 18-40, 30 (42.9\%) were 41-60, and 12 (17.1\%) were 60 years and older (Table 1). 41 (58.6\%) patients were female, 33 (47.1\%) patients were hospitalized more than 14 days. There were 3 (4.3\%) severe COVID-19 patients, among which two were cured and discharged from hospital, and the last was transferred to a provincial hospital for his congenital cerebral palsy. 18 (25.7\%) patients were residents of Wuhan or recently travelled to Wuhan, 38 (54.3\%) 
patients had close contact with COVID-19 patients, 5 (7.1) patients resided of Hubei province (except Wuhan) or travelled there, leaving 9 (12.9\%) patients with unknown epidemiological history whose jobs may involve making contacts with many people, such as taxi driver and shop assistant (others were still unknown).

Among the 70 COVID-19 patients, 28 (40.0\%) patients had pre-existing diseases. The most common pre-existing diseases were liver disease (15.7\%), hypertension (12.9\%), renal disease (8.6), and lung disease (5.7\%). The median Body Mass Index was 23.0 (IQR: 20.3-25.2), and the time from illness onset to hospitalization was 4 (IQR: 2-7) days.

\section{Clinical information}

Compared with the hospitalization day 1, the Clinical manifestations such as highest temperature, fatigue, and cough of the hospitalization last day were significantly better (Table 2). At the same time, the effect of the clinical outcomes were observed throughout the treatment period. The most common treatment regimen was Lopinavir/ritonavir (LPV) + Interferon alpha inhalation (IAI) + Arbidol, which ranges from the proportion of $58.7 \%$ in hospitalization day 1 to $74.2 \%$ in hospitalization last day. Patients suspected of and then confirmed at the hospital or confirmed patients in the early stage of the treatment, could use the single LPV from hospitalization day 1 to day4, and then transformed from the single drug to a combined antiviral treatment. 'LPV+ IAI+ Arbidol+ Antibiotics' was another common treatment, which ranged from the proportion of $1.6 \%$ on day 1 to $12.9 \%$ on day last. 69 (98.6\%) patients received antiviral treatment during the whole hospitalization period, only one patient receiving symptomatic treatment for her pre-existing diseases. 13 (18.6\%) patients received antibiotic treatment and 10 (14.3\%) patients received corticosteroid treatment during their hospitalization.

\section{Laboratory outcomes}

Compared with hospitalization day1, White blood cell count, C-reacting protein, Potassium, Aspartate aminotransferase, Lactate dehydrogenase, and Lactic acid were dropped significantly hospitalization the last day of hospitalization (Table 3). On day 1, 7 (11.7\%) patients diagnosed with leucopenia (white blood cell count $<3.5 \times 109 / \mathrm{L})$ and only $3(4.6 \%)$ still had leucopenia on the last day. The C-reacting protein (>10 mg/L), Lactate dehydrogenase $(>250 \mathrm{U} / \mathrm{L})$, and Aspartate aminotransferase ( $>40 \mathrm{U} / \mathrm{L})$ had higher levels of proportions in day 1 than last day, while the proportion of Potassium ( $\geq 3.5 \mathrm{mmol} / \mathrm{L})$ and Lactic acid $(>2.1 \mathrm{mmol} / \mathrm{L})$ were higher in last day of the hospitalization than day1. 28 (46.7\%) patients diagnosed with lymphopenia (lymphocyte count <1.0×109/L) in day1, 19 (29.3\%) showed lymphopenia in last day of hospitalization.

The proportion of serum amyloid-A $>10 \mathrm{mg} / \mathrm{L}$ had no significance between day 1 and day-last, although it was higher in day3, day4, and day6. The median of D-dimer ranged from 0.21 to 0.28 between day1 and last day, and the highest proportion of D-dimer (>0.55 mg/L) was in day6 with $6(28.6 \%)$ patients. $11(26.8 \%)$ patients had Arterial oxygen pressure less than $83 \mathrm{mmHg}$ on day1, and that number dropped to 5 (11.6\%) on the last day. In order to clearly demonstrate the temporal changes of the laboratory, a box plot was plotted in Fig 1.

\section{Radiography findings}

The median number of times a patients receiving chest computed tomography (CT) from day1 to day7 was 3 (IQR: 3-4), indicating that most patients had a chest CT every other day (Table 4). 62 (88.6\%) patients were first identified with a viral pneumonia, and the typical chest computed tomographic images were patchy shadows and ground glass opacity (Fig 2). There was only one patient whose chest CT was normal, the other seven patient were shown with Bronchitis (1), Fibrosis (2), Emphysema (1), and Pulmonary nodule (3), respectively. The most common performance of the CT result was Viral pneumonia+ better+ better (7, 10\%), and then was Viral pneumonia+ worse+ 
better+ better $(6,8.6 \%)$. There were 41 (74.5\%) patients having “Better+ Pulmonary inflammation" CT result before they were discharged from the hospital.

\section{Discussion}

We included 70 discharged COVID-19 patients from the designated Hangzhou Xixi hospital. The median hospitalization was 13.7 (10.2-17.0) days, which was longer than that in Wuhan(6). This may be related to the stricter standard of discharging in Zhejiang province, which required a swab sample negative based on the national standard (10). No significant difference was found in hospitalization between the pre-existing disease group ( $\mathrm{n}=28)$ and the group without $(\mathrm{n}=42)$. However, the median period of hospitalization among pre-existing group was 13.0 (IQR: 9.5-16.3), and the group without was 14.4 (IQR: 11.0-17.2). Considering the epidemiological of the 70 patients, 18 (25.7\%) patients were residents of Wuhan or had travelled to Wuhan, 38 (54.3\%) patients had a close contact with the COVID-19 patients, which may suggest the transmission from human to human found in the previous studies (5, 7).

Compared to Day1, Patients had better performances in body temperature, cough, and fatigue when they were discharged, and we can also observe the process of positive changes in clinical manifestations from hospitalization day1 to day last. 69 (98.6\%) patients received antiviral treatment, and most of them had "Lopinavir/ritonavir (LPV) + Interferon alpha inhalation +Arbidol" therapy. There are no specific antiviral therapies for COVID-19. However, LPV is an effective drug that inhibits the protease of coronavirus learning from SARS and MERS $(11,12)$. We assumed using LPV may have a positive effect in the treatment of COVID-19. The use of antibiotics and Corticosteroid was mainly based on the actual clinical needs of patients, which varied by patients. At the same time, we should also pay attention to the side effects of LPV, such as liver dysfunction and gastroenterological symptoms $(13,14)$. Some patients in our study stopped taking LPV because of its side effect.

There were some abnormal laboratory outcomes observed in our study, including leucopenia, Potassium and Sodium reduction, evaluated aspartate aminotransferase, high C-reacting protein and serum amyloid-A, improved lactic acid, and rising D-dimer. This suggests that the infection of SARS-CoV-2 could have an influence on cellular immune deficiency, kidney injury and kidney injury (6).

During the first seven days of hospitalization, most patients had a chest CT every other day in our study. The dynamic profile of the chest CT showed that many cases were getting better compared with previous CT images. Only one person with normal CT images during the whole treatment, which support the view of COVID-19 patients may have normal images (8). However, 41 (74.5\%) of 55 patients had a "better+ Pulmonary inflammation" CT image, only 2 (3.6\%) patients were normal before they were discharged. Although many patients had reached the standard of discharging, the basic physical conditions including liver function, kidney and CT image were still abnormal to some extent. Some discharged patients were nucleic acid positive during the follow-up, and we should pay more attention to those discharged patients in order to control the transmission of the infectious disease.

There are some limitations to our study. First, there were 70 discharged patients included in our study. A lot of patients were discharged from hospital as the data were collected, and we only collected the information in Hangzhou, Zhejiang Province. Second, some epidemiological data were obtained through talking to patients (recall bias), which were inevitably affected our assessment. Thirdly, some severe patients were not included in our analysis, as they were transferred to a provincial hospital. Fourth, there were inevitably some missing data in the laboratory outcomes and chest CT images. 


\section{Conclusion}

Currently, there are no specific antiviral therapies for COVID-19. 70 COVID-19 patients in our study responded positively to treatment during the two-week period. For those discharged patients with abnormal results, more attention is needed in the future studies to control the transmission.

\section{Abbreviations}

COVID-19: 2019-coronavirus disease;

SARS-CoV-2: severe acute respiratory syndrome coronavirus 2;

LPV: Lopinavir/ritonavir

WHO: World Health Organization;

CT: computed tomography;

IQR: interquartile range;

IAI: Interferon alpha inhalation

\section{Declarations}

\section{Ethics approval and consent to participate}

This study was approved by the Institutional Review Board of Xixi Hospital. All data were anonymous to comply with the provisions of personal data protection legislation.

\section{Consent for publication}

Not applicable

\section{Availability of data and materials}

The data set used for this manuscript will be available from the corresponding author upon reasonable request.

\section{Competing interests}

None declared.

\section{Funding}

The work was supported by Hangzhou science and Technology Bureau (Program: Research project on the prevention and treatment of COVID-19 in Hangzhou, Establishment of clinical diagnosis and treatment system for COVID-19 with treatment evaluation) (grant number: there was no grant number for this program).

\section{Authors' contributions}

Conceived and designed the research: JW, DS, AX. Data collection: MW, HN, WY, YC. Data analysis: ZZ, YJ, PL,DY. Wrote the paper: ZZ, YW. Reviewed and revised the paper: ZZ, JW. All authors read and approved the final 
manuscript.

\section{Acknowledgements}

We thank all study participants and staff of all participating sites.

\section{References}

1. Huang C, Wang Y, Li X, Ren L, Zhao J, Hu Y, et al. Clinical features of patients infected with 2019 novel coronavirus in Wuhan, China. Lancet (London, England). 2020;395(10223):497-506.

2. Lu R, Zhao X, Li J, Niu P, Yang B, Wu H, et al. Genomic characterisation and epidemiology of 2019 novel coronavirus: implications for virus origins and receptor binding. Lancet (London, England).

2020;395(10224):565-74.

3. World Health Organization. Coronavirus disease (COVID-19) outbreak 2020 [cited 2020 February 29]. Available from: https://www.who.int/.

4. National Health Commission of the People's Republic of China. 2020. Available from: http://www.nhc.gov.cn/xcs/xxgzbd/gzbd_index.shtml.

5. Chan JF, Yuan S, Kok KH, To KK, Chu H, Yang J, et al. A familial cluster of pneumonia associated with the 2019 novel coronavirus indicating person-to-person transmission: a study of a family cluster. Lancet (London, England). 2020;395(10223):514-23.

6. Wang D, Hu B, Hu C, Zhu F, Liu X, Zhang J, et al. Clinical Characteristics of 138 Hospitalized Patients With 2019 Novel Coronavirus-Infected Pneumonia in Wuhan, China. Jama. 2020.

7. Xu XW, Wu XX, Jiang XG, Xu KJ, Ying LJ, Ma CL, et al. Clinical findings in a group of patients infected with the 2019 novel coronavirus (SARS-Cov-2) outside of Wuhan, China: retrospective case series. 2020;368:m606.

8. Guan WJ, Ni ZY, Hu Y, Liang WH, Ou CQ, He JX, et al. Clinical Characteristics of Coronavirus Disease 2019 in China. The New England journal of medicine. 2020.

9. World Health Organization. Clinical management of severe acute respiratory infection when novel coronavirus (nCoV) infection is suspected: interim guidance. 2020 [cited 2020 February 29]. Available from:

https://www.who.int/publications-detail/clinical-management-of-severe-acute-respiratory-infection-when-novelcoronavirus-(ncov)-infection-is-suspected.

10. National Health Commission of the People's Republic of China, State Administration of Traditional Chinese Medicine. Diagnosis and treatment of novel coronavirus pneumonia (Trial version 6) 2020. Available from: http://www.nhc.gov.cn/yzygj/s7653p/202002/8334a8326dd94d329df351d7da8aefc2.shtml.

11. Sheahan TP, Sims AC, Leist SR, Schafer A, Won J, Brown AJ, et al. Comparative therapeutic efficacy of remdesivir and combination lopinavir, ritonavir, and interferon beta against MERS-CoV. Nature communications. 2020;11(1):222.

12. Yao TT, Qian JD, Zhu WY, Wang Y, Wang GQ. A Systematic Review of Lopinavir Therapy for SARS Coronavirus and MERS Coronavirus-A Possible Reference for Coronavirus Disease-19 Treatment Option. Journal of medical virology. 2020.

13. Huang X, Xu L, Sun L, Gao G, Cai W, Liu Y, et al. Six-Year Immunologic Recovery and Virological Suppression of HIV Patients on LPV/r-Based Second-Line Antiretroviral Treatment: A Multi-Center Real-World Cohort Study in China. Frontiers in pharmacology. 2019;10:1455. 
14. Cai J, Xiao J, Zhang Q. Side effects and tolerability of post-exposure prophylaxis with zidovudine, lamivudine, and lopinavir/ritonavir: a comparative study with HIV/AIDS patients. Chinese medical journal.

2014;127(14):2632-6.

\section{Tables}

Table 1 demographic and baseline characteristics of 70 discharged COVID-19 patients in Hangzhou, Zhejiang province

\begin{tabular}{ll}
\hline Variable & $\mathrm{N}(\%)$ \\
\hline Median (interquartile) age (years) & $43(34-56)$ \\
Age (years) & $2(2.9)$ \\
$\leq 18$ & $26(37.1)$ \\
$18-40$ & $30(42.9)$ \\
$41-60$ & $12(17.1)$ \\
$\geq 60$ & \\
Gender & $41(58.6)$ \\
Female & $29(41.4)$ \\
Male & \\
Epidemiology & $18(25.7)$ \\
Wuhan & $38(54.3)$ \\
Close contact with COVID-19 patients & $9(12.9)$ \\
Unknown & $5(7.1)$ \\
Hubei (except for Wuhan) & $23.0(20.3-25.2)$ \\
Body Mass Index & \\
Basic disease & $28(40.0)$ \\
Any & $9(12.9)$ \\
Hypertension & $1(1.4)$ \\
Diabetes & $3(4.3)$ \\
Hyperlipidemia & $2(2.9)$ \\
Heart disease & $11(15.7)$ \\
Liver disease & $6(8.6)$ \\
Renal disease & $4(5.7)$ \\
Lung disease & $1(1.4)$ \\
Cerebral palsy & $1(1.4)$ \\
Anemia & \\
Disease progression & $67(95.7)$ \\
Non-severe & $3(4.3)$ \\
Severe & $13.7(10.2-17.0)$ \\
Hospital stay & $37(52.9)$ \\
s14 & $33(47.1)$ \\
Time from illness onset to hospitalization (days) & $4(2-7)$ \\
\hline
\end{tabular}

Values are median (interquartile ranges).

Table 2 clinical information of 70 discharged COVID-19 patients in Hangzhou, Zhejiang province. 


\begin{tabular}{|c|c|c|c|c|c|c|c|c|c|}
\hline \multirow[t]{2}{*}{ Variable } & \multicolumn{8}{|c|}{ Hospital admission } & \multirow[b]{2}{*}{$\begin{array}{l}\text { P (Day } 1 \\
\text { VS Last } \\
\text { day) }\end{array}$} \\
\hline & Day 1 & Day 2 & Day 3 & Day 4 & Day 5 & Day 6 & Day 7 & $\begin{array}{r}\text { Last } \\
\text { day }\end{array}$ & \\
\hline Highest temperature $\left({ }^{\circ} \mathrm{C}\right)$ & $\begin{array}{l}37 \\
(36.7- \\
376)\end{array}$ & $\begin{array}{c}36.9 \\
(36.7- \\
37.5)\end{array}$ & $\begin{array}{l}37 \\
(36.7- \\
374)\end{array}$ & $\begin{array}{c}36.9 \\
(36.5- \\
373)\end{array}$ & $\begin{array}{c}36.7 \\
(36.5- \\
37.2)\end{array}$ & $\begin{array}{c}36.9 \\
(36.4- \\
371)\end{array}$ & $\begin{array}{c}36.8 \\
(36.7- \\
372)\end{array}$ & $\begin{array}{l}36.8 \\
(36.5- \\
37)\end{array}$ & $<0.0001$ \\
\hline$<37.3$ & $\begin{array}{l}43 \\
(61.4)\end{array}$ & $\begin{array}{l}49 \\
(70.0)\end{array}$ & $\begin{array}{l}50 \\
(71.4)\end{array}$ & $\begin{array}{l}50 \\
(71.4)\end{array}$ & $\begin{array}{l}57 \\
(81.4)\end{array}$ & $\begin{array}{l}59 \\
(84.3)\end{array}$ & $\begin{array}{l}57 \\
(81.4)\end{array}$ & $\begin{array}{l}67 \\
(95.7)\end{array}$ & \\
\hline $37.3-38$ & $\begin{array}{l}15 \\
(21.4)\end{array}$ & $\begin{array}{l}11 \\
(15.7)\end{array}$ & $\begin{array}{l}15 \\
(21.5)\end{array}$ & $\begin{array}{l}19 \\
(27.2)\end{array}$ & $\begin{array}{l}11 \\
(15.7)\end{array}$ & $\begin{array}{l}10 \\
(14.3)\end{array}$ & $\begin{array}{l}13 \\
(18.6)\end{array}$ & $\begin{array}{l}3 \\
(4.3)\end{array}$ & \\
\hline $38.1-39$ & $\begin{array}{l}12 \\
(17.2)\end{array}$ & $\begin{array}{l}8 \\
(11.4)\end{array}$ & $\begin{array}{l}4 \\
(5.7)\end{array}$ & & $\begin{array}{l}2 \\
(2.9)\end{array}$ & $\begin{array}{l}1 \\
(1.4)\end{array}$ & & & \\
\hline$\geq 39$ & & $\begin{array}{l}2 \\
(2.9)\end{array}$ & $\begin{array}{l}1 \\
(1.4)\end{array}$ & $\begin{array}{l}1 \\
(1.4)\end{array}$ & & & & & \\
\hline fatigue & & & & & & & & & 0.02 \\
\hline Yes & $\begin{array}{l}16 \\
(22.9)\end{array}$ & $\begin{array}{l}16 \\
(22.9)\end{array}$ & $\begin{array}{l}12 \\
(17.1)\end{array}$ & $\begin{array}{l}14 \\
(20.0)\end{array}$ & $\begin{array}{l}16 \\
(23.2)\end{array}$ & $\begin{array}{l}17 \\
(25.0)\end{array}$ & $\begin{array}{l}16 \\
(23.9)\end{array}$ & $\begin{array}{l}5 \\
(7.7)\end{array}$ & \\
\hline No & $\begin{array}{l}54 \\
(77.1)\end{array}$ & $\begin{array}{l}54 \\
(77.1)\end{array}$ & $\begin{array}{l}58 \\
(82.9)\end{array}$ & $\begin{array}{l}56 \\
(80.0)\end{array}$ & $\begin{array}{l}53 \\
(76.8)\end{array}$ & $\begin{array}{l}51 \\
(75.0)\end{array}$ & $\begin{array}{l}51 \\
(76.1)\end{array}$ & $\begin{array}{l}60 \\
(92.3)\end{array}$ & \\
\hline Cough & & & & & & & & & 0.01 \\
\hline Yes & $\begin{array}{l}33 \\
(47.1)\end{array}$ & $\begin{array}{l}33 \\
(47.1)\end{array}$ & $\begin{array}{l}29 \\
(41.4)\end{array}$ & $\begin{array}{l}27 \\
(38.6)\end{array}$ & $\begin{array}{l}19 \\
(27.5)\end{array}$ & $\begin{array}{l}22 \\
(32.3)\end{array}$ & $\begin{array}{l}21 \\
(31.3)\end{array}$ & $\begin{array}{l}16 \\
(24.6)\end{array}$ & \\
\hline No & $\begin{array}{l}37 \\
(52.9)\end{array}$ & $\begin{array}{l}37 \\
(52.9)\end{array}$ & $\begin{array}{l}41 \\
(58.6)\end{array}$ & $\begin{array}{l}43 \\
(61.4)\end{array}$ & $\begin{array}{l}50 \\
(72.5)\end{array}$ & $\begin{array}{l}46 \\
(67.7)\end{array}$ & $\begin{array}{l}46 \\
(68.7)\end{array}$ & $\begin{array}{l}49 \\
(75.4)\end{array}$ & \\
\hline \multicolumn{10}{|l|}{ Treatment } \\
\hline LPV & $\begin{array}{l}5 \\
(7.9)\end{array}$ & $\begin{array}{l}2 \\
(2.9)\end{array}$ & $\begin{array}{l}2 \\
(2.9)\end{array}$ & $\begin{array}{l}1 \\
(1.4)\end{array}$ & & & & & \\
\hline Arbidol & & & & & $\begin{array}{l}1 \\
(1.4)\end{array}$ & $\begin{array}{l}1 \\
(1.4)\end{array}$ & $\begin{array}{l}1 \\
(1.5)\end{array}$ & $\begin{array}{l}1 \\
(1.5)\end{array}$ & \\
\hline LPV+ IAI & $\begin{array}{l}5 \\
(7.9)\end{array}$ & $\begin{array}{l}4 \\
(5.9)\end{array}$ & $\begin{array}{l}4 \\
(5.8)\end{array}$ & $\begin{array}{l}4 \\
(5.7)\end{array}$ & $\begin{array}{l}2 \\
(2.9)\end{array}$ & $\begin{array}{l}1 \\
(1.4)\end{array}$ & $\begin{array}{l}2 \\
(3.0)\end{array}$ & $\begin{array}{l}1 \\
(1.5)\end{array}$ & \\
\hline LPV+ Arbidol & $\begin{array}{l}8 \\
(12.7)\end{array}$ & $\begin{array}{l}2 \\
(2.9)\end{array}$ & $\begin{array}{l}2 \\
(2.9)\end{array}$ & $\begin{array}{l}1 \\
(1.4)\end{array}$ & $\begin{array}{l}2 \\
(2.9)\end{array}$ & & & & \\
\hline Arbidol+ IAI & & & & $\begin{array}{l}2 \\
(2.9)\end{array}$ & $\begin{array}{l}2 \\
(2.9)\end{array}$ & $\begin{array}{l}3 \\
(4.4)\end{array}$ & $\begin{array}{l}5 \\
(7.5)\end{array}$ & $\begin{array}{l}5 \\
(7.6)\end{array}$ & \\
\hline LPV+ Antibiotics & & & $\begin{array}{l}1 \\
(1.5)\end{array}$ & $\begin{array}{l}1 \\
(1.4)\end{array}$ & $\begin{array}{l}1 \\
(1.4)\end{array}$ & $\begin{array}{l}1 \\
(1.4)\end{array}$ & $\begin{array}{l}1 \\
(1.5)\end{array}$ & $\begin{array}{l}1 \\
(1.5)\end{array}$ & \\
\hline IAI+ Arbidol+ Corticosteroid & & & & $\begin{array}{l}1 \\
(1.4)\end{array}$ & $\begin{array}{l}2 \\
(2.9)\end{array}$ & $\begin{array}{l}1 \\
(1.4)\end{array}$ & $\begin{array}{l}1 \\
(1.5)\end{array}$ & $\begin{array}{l}1 \\
(1.5)\end{array}$ & \\
\hline LPV+IAI+Arbidol & $\begin{array}{l}37 \\
(58.7)\end{array}$ & $\begin{array}{l}44 \\
(64.7)\end{array}$ & $\begin{array}{l}46 \\
(66.7)\end{array}$ & $\begin{array}{l}46 \\
(65.7)\end{array}$ & $\begin{array}{l}45 \\
(64.3)\end{array}$ & $\begin{array}{l}49 \\
(72.1)\end{array}$ & $\begin{array}{l}44 \\
(65.7)\end{array}$ & $\begin{array}{l}49 \\
(74.2)\end{array}$ & \\
\hline LPV+IAI+Arbidol+Corticosteroid & $\begin{array}{l}1 \\
(1.6)\end{array}$ & $\begin{array}{l}3 \\
(4.4)\end{array}$ & $\begin{array}{l}4 \\
(5.8)\end{array}$ & $\begin{array}{l}3 \\
(4.3)\end{array}$ & $\begin{array}{l}5 \\
(7.1)\end{array}$ & $\begin{array}{l}4 \\
(5.9)\end{array}$ & $\begin{array}{l}4 \\
(6.0)\end{array}$ & & \\
\hline LPV+IAI+Arbidol+Corticosteroid+Antibiotics & $\begin{array}{l}1 \\
(1.6)\end{array}$ & $\begin{array}{l}2 \\
(2.9)\end{array}$ & & $\begin{array}{l}1 \\
(1.4)\end{array}$ & $\begin{array}{l}1 \\
(1.4)\end{array}$ & $\begin{array}{l}1 \\
(1.4)\end{array}$ & $\begin{array}{l}1 \\
(1.5)\end{array}$ & & \\
\hline LPV+IAI+Arbidol+Antibiotics & $\begin{array}{l}1 \\
(1.6)\end{array}$ & $\begin{array}{l}6 \\
(8.8)\end{array}$ & $\begin{array}{l}8 \\
(11.6)\end{array}$ & $\begin{array}{l}9 \\
(12.9)\end{array}$ & $\begin{array}{l}8 \\
(11.4)\end{array}$ & $\begin{array}{l}5 \\
(7.4)\end{array}$ & $\begin{array}{l}7 \\
(10.5)\end{array}$ & $\begin{array}{l}7 \\
(10.6)\end{array}$ & \\
\hline Symptomatic treatment & $\begin{array}{l}5 \\
(7.9) \\
\end{array}$ & $\begin{array}{l}2 \\
(2.9) \\
\end{array}$ & $\begin{array}{l}2 \\
(2.9) \\
\end{array}$ & $\begin{array}{l}1 \\
(1.4)\end{array}$ & $\begin{array}{l}1 \\
(1.4) \\
\end{array}$ & $\begin{array}{l}1 \\
(1.4)\end{array}$ & $\begin{array}{l}1 \\
(1.5)\end{array}$ & $\begin{array}{l}1 \\
(1.5) \\
\end{array}$ & \\
\hline
\end{tabular}

Values are median (interquartile ranges). LPV: Lopinavir/ritonavir, IAI: Interferon alpha inhalation.

Table 3 Laboratory outcomes of 70 discharged COVID-19 patients in Hangzhou, Zhejiang province. 


\begin{tabular}{|c|c|c|c|c|c|c|c|c|c|}
\hline \multirow[t]{2}{*}{ Variable } & \multicolumn{8}{|c|}{ Hospital admission } & \multirow[b]{2}{*}{$\begin{array}{l}\text { P (Day } 1 \text { VS } \\
\text { Last day) }\end{array}$} \\
\hline & Day 1 & Day 2 & Day 3 & Day 4 & Day 5 & Day 6 & Day 7 & $\begin{array}{l}\text { Last } \\
\text { day }\end{array}$ & \\
\hline $\begin{array}{l}\text { White blood cell count }\left(\times 10^{9} / \mathrm{L} \text {; }\right. \\
\text { normal range } 3.5-9.5)\end{array}$ & & & & & & & & & 0.004 \\
\hline$<3.5$ & $\begin{array}{l}7 \\
(11.7)\end{array}$ & $2(5.4)$ & $3(7.3)$ & $3(6.8)$ & $2(5.0)$ & $2(7.1)$ & $1(3.1)$ & $3(4.6)$ & \\
\hline $3.5-9.5$ & $\begin{array}{l}47 \\
(78.3)\end{array}$ & $\begin{array}{l}31 \\
(83.8)\end{array}$ & $\begin{array}{l}35 \\
(85.4)\end{array}$ & $\begin{array}{l}38 \\
(86.4)\end{array}$ & $\begin{array}{l}36 \\
(90.0)\end{array}$ & $\begin{array}{l}25 \\
(89.3)\end{array}$ & $\begin{array}{l}28 \\
(87.5)\end{array}$ & $\begin{array}{l}60 \\
(92.3)\end{array}$ & \\
\hline$\geq 9.5$ & 6 & $\begin{array}{l}4 \\
(10.8)\end{array}$ & $3(7.3)$ & $3(6.8)$ & $2(5.0)$ & $1(3.6)$ & $3(9.4)$ & $2(3.1)$ & \\
\hline $\begin{array}{l}\text { Lymphocyte count }\left(\times 10^{9} / \mathrm{L} \text {; normal }\right. \\
\text { range:1.1-3.2) }\end{array}$ & $\begin{array}{l}1.2 \\
(0.8- \\
1.8)\end{array}$ & $\begin{array}{l}1.3 \\
(1.0- \\
1.7)\end{array}$ & $\begin{array}{l}1.3 \\
(1.0- \\
1.9)\end{array}$ & $\begin{array}{l}1.3 \\
(1.0- \\
1.6)\end{array}$ & $\begin{array}{l}1.2 \\
(1.0- \\
1.5)\end{array}$ & $\begin{array}{l}1.1 \\
(0.8- \\
1.3)\end{array}$ & $\begin{array}{l}1.2 \\
(0.9- \\
1.7)\end{array}$ & $\begin{array}{l}1.3 \\
(1.1- \\
1.6)\end{array}$ & 0.13 \\
\hline$<1.1$ & $\begin{array}{l}28 \\
(46.7)\end{array}$ & $\begin{array}{l}11 \\
(29.7)\end{array}$ & $\begin{array}{l}13 \\
(31.7)\end{array}$ & $\begin{array}{l}13 \\
(29.5)\end{array}$ & $\begin{array}{l}12 \\
(30.0)\end{array}$ & $\begin{array}{l}15 \\
(53.6)\end{array}$ & $\begin{array}{l}14 \\
(43.7)\end{array}$ & $\begin{array}{l}19 \\
(29.3)\end{array}$ & \\
\hline $1.1-3.2$ & $\begin{array}{l}31 \\
(51.7)\end{array}$ & $\begin{array}{l}25 \\
(67.6)\end{array}$ & $\begin{array}{l}26 \\
(63.4)\end{array}$ & $\begin{array}{l}30 \\
(68.2)\end{array}$ & $\begin{array}{l}27 \\
(67.5)\end{array}$ & $\begin{array}{l}13 \\
(46.4)\end{array}$ & $\begin{array}{l}18 \\
(56.3)\end{array}$ & $\begin{array}{l}45 \\
(69.2)\end{array}$ & \\
\hline$>3.2$ & $1(1.6)$ & $1(2.7)$ & $2(4.9)$ & $1(2.3)$ & $1(2.5)$ & & & $1(1.5)$ & \\
\hline $\begin{array}{l}\text { C-reacting protein }(\mathrm{mg} / \mathrm{L} ; \text { normal } \\
\text { range: }<10)\end{array}$ & & & & & & & & & 0.008 \\
\hline$<1$ & $\begin{array}{l}12 \\
(20.8)\end{array}$ & $\begin{array}{l}9 \\
(24.3)\end{array}$ & $\begin{array}{l}10 \\
(26.3)\end{array}$ & $\begin{array}{l}9 \\
(22.0)\end{array}$ & $\begin{array}{l}7 \\
(19.4)\end{array}$ & $\begin{array}{l}3 \\
(12.0)\end{array}$ & $\begin{array}{l}8 \\
(28.6)\end{array}$ & $\begin{array}{l}28 \\
(43.7)\end{array}$ & \\
\hline $1-10$ & $\begin{array}{l}23 \\
(39.6)\end{array}$ & $\begin{array}{l}13 \\
(35.1)\end{array}$ & $\begin{array}{l}12 \\
(31.6)\end{array}$ & $\begin{array}{l}13 \\
(31.7)\end{array}$ & $\begin{array}{l}10 \\
(27.8)\end{array}$ & $\begin{array}{l}6 \\
(24.0)\end{array}$ & $\begin{array}{l}10 \\
(35.7)\end{array}$ & $\begin{array}{l}24 \\
(37.5)\end{array}$ & \\
\hline$>10$ & $\begin{array}{l}23 \\
(39.6)\end{array}$ & $\begin{array}{l}15 \\
(40.6)\end{array}$ & $\begin{array}{l}16 \\
(42.1)\end{array}$ & $\begin{array}{l}19 \\
(46.3)\end{array}$ & $\begin{array}{l}19 \\
(52.8)\end{array}$ & $\begin{array}{l}16 \\
(64.0)\end{array}$ & $\begin{array}{l}10 \\
(35.7)\end{array}$ & $\begin{array}{l}12 \\
(18.8)\end{array}$ & \\
\hline $\begin{array}{l}\text { serum amyloid-A (mg/L; normal } \\
\text { range: }<10)\end{array}$ & & & & & & & & & 0.17 \\
\hline $1-10$ & $\begin{array}{l}13 \\
(28.9)\end{array}$ & $\begin{array}{l}9 \\
(31.0)\end{array}$ & $\begin{array}{l}5 \\
(16.1)\end{array}$ & $\begin{array}{l}6 \\
(17.7)\end{array}$ & $\begin{array}{l}4 \\
(15.4)\end{array}$ & $\begin{array}{l}5 \\
(25.0)\end{array}$ & $\begin{array}{l}3 \\
(13.0)\end{array}$ & $\begin{array}{l}17 \\
(31.5)\end{array}$ & \\
\hline$>10$ & $\begin{array}{l}32 \\
(71.1)\end{array}$ & $\begin{array}{l}20 \\
(69.0)\end{array}$ & $\begin{array}{l}26 \\
(83.9)\end{array}$ & $\begin{array}{l}28 \\
(82.3)\end{array}$ & $\begin{array}{l}22 \\
(84.6)\end{array}$ & $\begin{array}{l}15 \\
(75.0)\end{array}$ & $\begin{array}{l}20 \\
(87.0)\end{array}$ & $\begin{array}{l}37 \\
(68.5)\end{array}$ & \\
\hline $\begin{array}{l}\text { Potassium (mmol/L; normal range: } \\
\text { 3.5-5.3) }\end{array}$ & $\begin{array}{l}3.7 \\
(3.5- \\
4.0)\end{array}$ & $\begin{array}{l}3.7 \\
(3.6- \\
3.9)\end{array}$ & $\begin{array}{l}3.7 \\
(3.4- \\
4.0)\end{array}$ & $\begin{array}{l}3.6 \\
(3.4- \\
3.9)\end{array}$ & $\begin{array}{l}3.7 \\
(3.6- \\
3.9)\end{array}$ & $\begin{array}{l}3.7 \\
(3.5- \\
3.9)\end{array}$ & $\begin{array}{l}3.7 \\
(3.5- \\
4.0)\end{array}$ & $\begin{array}{l}3.9 \\
(3.7- \\
4.0)\end{array}$ & 0.04 \\
\hline$<3.5$ & $\begin{array}{l}11 \\
(28.2)\end{array}$ & $\begin{array}{l}10 \\
(20.8)\end{array}$ & $\begin{array}{l}13 \\
(32.5)\end{array}$ & $\begin{array}{l}15 \\
(36.6)\end{array}$ & $\begin{array}{l}8 \\
(21.6)\end{array}$ & $\begin{array}{l}4 \\
(14.8)\end{array}$ & 6 & $\begin{array}{l}9 \\
(13.6)\end{array}$ & \\
\hline $3.5-5.3$ & $\begin{array}{l}28 \\
(71.8)\end{array}$ & $\begin{array}{l}38 \\
(79.2)\end{array}$ & $\begin{array}{l}27 \\
(67.5)\end{array}$ & $\begin{array}{l}26 \\
(63.4)\end{array}$ & $\begin{array}{l}29 \\
(78.4)\end{array}$ & $\begin{array}{l}23 \\
(85.2)\end{array}$ & $\begin{array}{l}28 \\
(82.4)\end{array}$ & $\begin{array}{l}57 \\
(86.4)\end{array}$ & \\
\hline $\begin{array}{l}\text { Aspartate aminotransferase (U/L; } \\
\text { normal range: } 15-40)\end{array}$ & & & & & & & & & 0.04 \\
\hline Decreased+ Normal & $\begin{array}{l}29 \\
(78.4)\end{array}$ & $\begin{array}{l}43 \\
(91.5)\end{array}$ & $\begin{array}{l}36 \\
(92.3)\end{array}$ & $\begin{array}{l}40 \\
(100.0)\end{array}$ & $\begin{array}{l}38 \\
(100.0)\end{array}$ & $\begin{array}{l}26 \\
(100.0)\end{array}$ & $\begin{array}{l}30 \\
(93.7)\end{array}$ & $\begin{array}{l}61 \\
(92.4)\end{array}$ & \\
\hline Increased & $\begin{array}{l}8 \\
(21.6)\end{array}$ & $4(8.5)$ & $3(7.7)$ & & & & $2(6.3)$ & $5(7.6)$ & \\
\hline $\begin{array}{l}\text { Creatinine (umol/L; normal range: } \\
57-111 \text { ) }\end{array}$ & & & & & & & & & 0.5 \\
\hline Decreased & $\begin{array}{l}19 \\
(50.0)\end{array}$ & $\begin{array}{l}21 \\
(43.7)\end{array}$ & $\begin{array}{l}12 \\
(30.0)\end{array}$ & $\begin{array}{l}10 \\
(24.4)\end{array}$ & $\begin{array}{l}15 \\
(39.5)\end{array}$ & $\begin{array}{l}9 \\
(34.6)\end{array}$ & $\begin{array}{l}25 \\
(75.8)\end{array}$ & $\begin{array}{l}26 \\
(39.4)\end{array}$ & \\
\hline Normal & $\begin{array}{l}18 \\
(47.4)\end{array}$ & $\begin{array}{l}26 \\
(54.2)\end{array}$ & $\begin{array}{l}26 \\
(65.0)\end{array}$ & $\begin{array}{l}30 \\
(73.2)\end{array}$ & $\begin{array}{l}20 \\
(52.6)\end{array}$ & $\begin{array}{l}17 \\
(65.4)\end{array}$ & $1(3.0)$ & $\begin{array}{l}39 \\
(59.1)\end{array}$ & \\
\hline Increased & $1(2.6)$ & $1(2.1)$ & $2(5.0)$ & $1(2.4)$ & $3(7.9)$ & & & $1(1.5)$ & \\
\hline $\begin{array}{l}\text { Lactate dehydrogenase } \quad(\mathrm{U} / \mathrm{L} \text {; } \\
\text { normal range:120-250) }\end{array}$ & & & & & & & & & $<0.001$ \\
\hline Decreased & $3(8.8)$ & $3(7.9)$ & $1(3.6)$ & $\begin{array}{l}4 \\
(14.3)\end{array}$ & $\begin{array}{l}4 \\
(16.0)\end{array}$ & $\begin{array}{l}4 \\
(17.4)\end{array}$ & $\begin{array}{l}3 \\
(11.1)\end{array}$ & $\begin{array}{l}7 \\
(13.2)\end{array}$ & \\
\hline Normal & $\begin{array}{l}15 \\
(44.1)\end{array}$ & $\begin{array}{l}29 \\
(76.3)\end{array}$ & $\begin{array}{l}22 \\
(78.6)\end{array}$ & $\begin{array}{l}24 \\
(85.7)\end{array}$ & $\begin{array}{l}20 \\
(80.0)\end{array}$ & $\begin{array}{l}16 \\
(69.6)\end{array}$ & $\begin{array}{l}21 \\
(77.8)\end{array}$ & $\begin{array}{l}44 \\
(83.0)\end{array}$ & \\
\hline Increased & $\begin{array}{l}16 \\
(47.1)\end{array}$ & $\begin{array}{l}6 \\
(15.8)\end{array}$ & $\begin{array}{l}5 \\
(17.8)\end{array}$ & & $1(4.0)$ & $3(3.0)$ & $\begin{array}{l}3 \\
(11.1)\end{array}$ & $2(3.8)$ & \\
\hline $\begin{array}{l}\text { Lactic acid (mmol/L; normal range: } \\
0.7-2.1)\end{array}$ & & & & & & & & & 0.001 \\
\hline Decreased + Normal & $\begin{array}{l}33 \\
(70.2)\end{array}$ & $\begin{array}{l}18 \\
(75.0)\end{array}$ & $\begin{array}{l}14 \\
(70.0)\end{array}$ & $\begin{array}{l}20 \\
(71.4)\end{array}$ & $\begin{array}{l}13 \\
(68.4)\end{array}$ & $\begin{array}{l}7 \\
(43.7)\end{array}$ & $\begin{array}{l}5 \\
(29.4)\end{array}$ & $\begin{array}{l}14 \\
(35.0)\end{array}$ & \\
\hline Increased & $\begin{array}{l}14 \\
(29.8)\end{array}$ & $\begin{array}{l}6 \\
(25.0)\end{array}$ & $\begin{array}{l}6 \\
(30.0)\end{array}$ & $\begin{array}{l}8 \\
(28.6)\end{array}$ & $\begin{array}{l}6 \\
(31.6)\end{array}$ & $\begin{array}{l}9 \\
(56.3)\end{array}$ & $\begin{array}{l}12 \\
(70.6)\end{array}$ & $\begin{array}{l}26 \\
(65.0)\end{array}$ & \\
\hline $\begin{array}{l}\text { D-dimer (mg/L; normal range: } 0 \text { - } \\
0.55)\end{array}$ & & & & & & & & & 0.27 \\
\hline Normal & $\begin{array}{l}48 \\
(84.2)\end{array}$ & $\begin{array}{l}17 \\
(80.9)\end{array}$ & $\begin{array}{l}21 \\
(72.4)\end{array}$ & $\begin{array}{l}25 \\
(78.1)\end{array}$ & $\begin{array}{l}25 \\
(86.2)\end{array}$ & $\begin{array}{l}15 \\
(71.4)\end{array}$ & $\begin{array}{l}24 \\
(80.0)\end{array}$ & $\begin{array}{l}41 \\
(75.9)\end{array}$ & \\
\hline Increased & $\begin{array}{l}9 \\
(15.8)\end{array}$ & $\begin{array}{l}4 \\
(19.1)\end{array}$ & $\begin{array}{l}8 \\
(27.6)\end{array}$ & $\begin{array}{l}7 \\
(21.9)\end{array}$ & $\begin{array}{l}4 \\
(13.8)\end{array}$ & $\begin{array}{l}6 \\
(28.6)\end{array}$ & $\begin{array}{l}6 \\
(20.0)\end{array}$ & $\begin{array}{l}13 \\
(24.1)\end{array}$ & \\
\hline $\begin{array}{l}\text { Arterial oxygen pressure (mmHg; } \\
\text { normal range: } 83-108)\end{array}$ & & & & & & & & & 0.07 \\
\hline Decreased & 11 & 4 & 8 & 6 & 4 & 4 & 3 & 5 & \\
\hline
\end{tabular}


Table 4 Radiography results of 70 discharged COVID-19 patients in Hangzhou, Zhejiang province.

\begin{tabular}{|c|c|}
\hline Variable & N (\%) \\
\hline Number of times a patients receiving CT among day 1-7 of radiography $(n=70)$ & $3(3-4)$ \\
\hline 1 time & $2(2.9)$ \\
\hline Viral pneumonia & $1(1.4)$ \\
\hline Pulmonary nodule & $1(1.4)$ \\
\hline 2 times & $13(18.6)$ \\
\hline Viral pneumonia+ same & $3(4.3)$ \\
\hline Viral pneumonia+ better & $5(7.1)$ \\
\hline Viral pneumonia+ worse & $1(1.4)$ \\
\hline Pulmonary nodule+ same & $2(2.9)$ \\
\hline Emphysema+ same & $1(1.4)$ \\
\hline Normal+ normal & $1(1.4)$ \\
\hline 3 times & $26(37.1)$ \\
\hline Fibrosis+ same+ same & $2(2.9)$ \\
\hline Viral pneumonia+ better+ better & $7(10)$ \\
\hline Viral pneumonia+ better+ normal & $1(1.4)$ \\
\hline Viral pneumonia+ better+ worse & $2(2.9)$ \\
\hline Viral pneumonia+ same+ better & $3(4.3)$ \\
\hline Viral pneumonia+ same+ same & $1(1.4)$ \\
\hline Viral pneumonia+ same+ worse & $1(1.4)$ \\
\hline Viral pneumonia+ worse+ better & $2(2.9)$ \\
\hline Viral pneumonia+ worse+ same & $2(2.9)$ \\
\hline Viral pneumonia+ worse+ worse & $4(5.7)$ \\
\hline Bronchitis+ same+ better & $1(1.4)$ \\
\hline 4 times & $20(28.6)$ \\
\hline Viral pneumonia+ better+ worse+ better & $1(1.4)$ \\
\hline Viral pneumonia+ worse+ better+ better & $6(8.6)$ \\
\hline Viral pneumonia+ worse+ same+ better & $1(1.4)$ \\
\hline Viral pneumonia+ worse+ worse+ better & $4(5.7)$ \\
\hline Viral pneumonia+ worse+ worse+ same & $1(1.4)$ \\
\hline Viral pneumonia+ worse+ worse+ better & $1(1.4)$ \\
\hline Viral pneumonia+ worse+ worse+ same & $1(1.4)$ \\
\hline Viral pneumonia+ same+ same+ same & $2(2.9)$ \\
\hline Viral pneumonia+ same+ better+ better & $1(1.4)$ \\
\hline Viral pneumonia+ same+ worse+ worse & $1(1.4)$ \\
\hline Viral pneumonia+ same+ worse+ better & $1(1.4)$ \\
\hline 5 times & $9(12.8)$ \\
\hline Viral pneumonia+ worse+ better + worse+ same & $1(1.4)$ \\
\hline Viral pneumonia+ worse+ same + better + better & $3(4.3)$ \\
\hline Viral pneumonia+ worse+ worse+ better + worse & $1(1.4)$ \\
\hline Viral pneumonia+ same + worse + same + worse & $1(1.4)$ \\
\hline Viral pneumonia + same + same + better + better & $1(1.4)$ \\
\hline Viral pneumonia+ same+ better+ better+ same & $1(1.4)$ \\
\hline Viral pneumonia+ same+ same+ same+ same & $1(1.4)$ \\
\hline \multicolumn{2}{|l|}{ The final CT results ( $\mathrm{C}=55,15$ missing data) } \\
\hline Fibrosis & $1(1.8)$ \\
\hline Normal & $2(3.6)$ \\
\hline Better+ Pulmonary nodule & $1(1.8)$ \\
\hline Better+ Pulmonary inflammation & $41(74.5)$ \\
\hline Same+ Pulmonary nodule & $2(3.6)$ \\
\hline Worse+ fibrosis & $1(1.8)$ \\
\hline Worse+ Pulmonary inflammation & $1(1.8)$ \\
\hline Same+ Pulmonary nodule + fibrosis & $1(1.8)$ \\
\hline Same+ Pulmonary nodule+ Emphysema & $1(1.8)$ \\
\hline Better+ Pulmonary inflammation+ Emphysema & $1(1.8)$ \\
\hline Worse+ Pulmonary inflammation + Emphysema & 1 (1.8) \\
\hline Better+ Pulmonary inflammation+ Pulmonary nodule & $2(3.6)$ \\
\hline
\end{tabular}

Same : images that show the same patterns as previous result; Better: a better result compare with a previous image, such as the absorption of bilateral ground glass; Worse: images that show a bad result compare with a previous image, such as the expansion of bilateral ground glass; Normal: CT images that demonstrate normal.

\section{Figures}



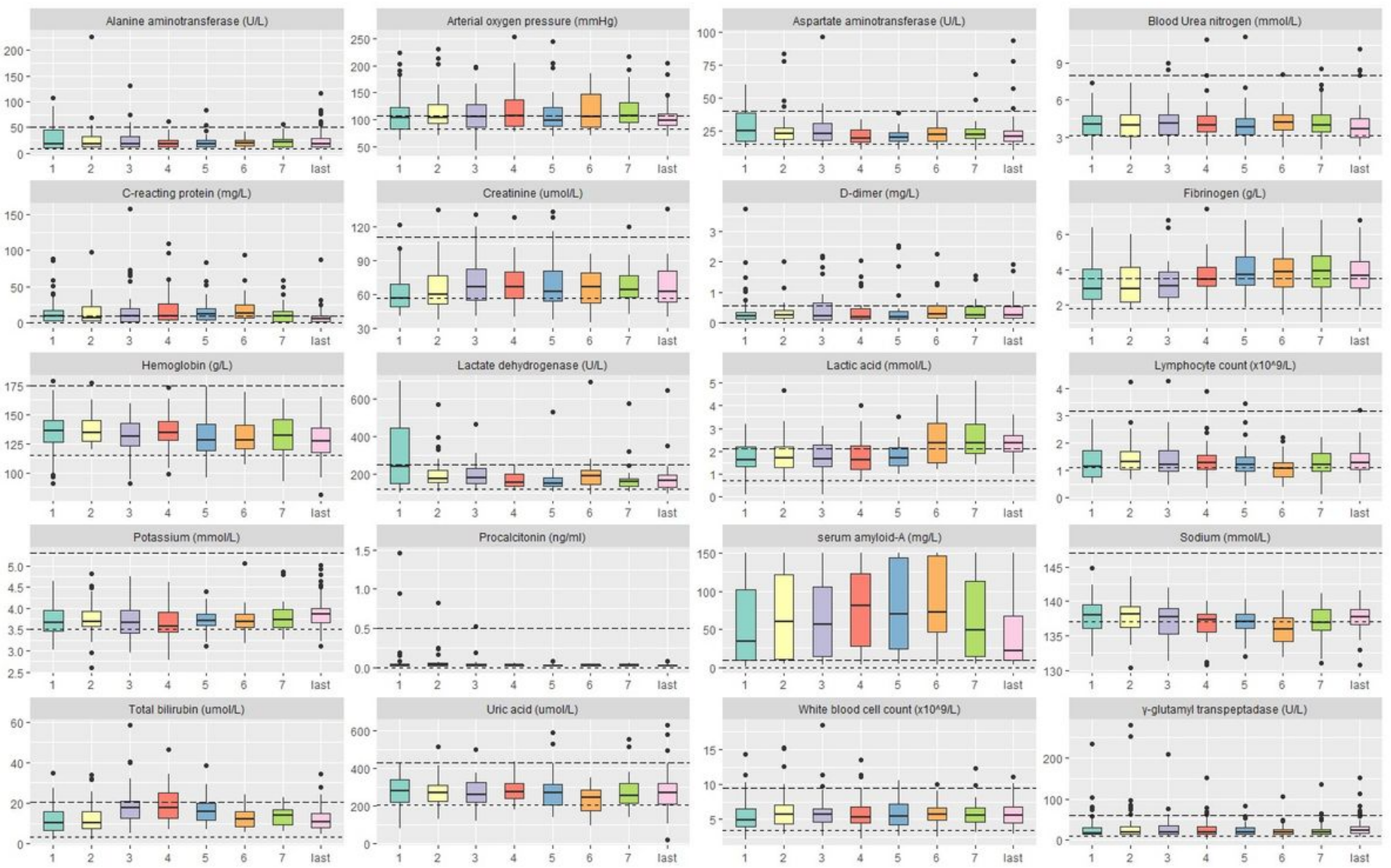

\section{Figure 1}

Chest radiographs in COVID-19 patients. (A) Chest computed tomographic images in hospitalization day 1 show ground glass opacity in both lungs; (B) Chest computed tomographic images in hospitalization day 5 show the absorption of ground glass opacity in both lungs (compare with A); (C) Chest computed tomographic images in hospitalization day last (10) show the absorption of both ground glass opacity (compare with B) and there were also inflammations. 

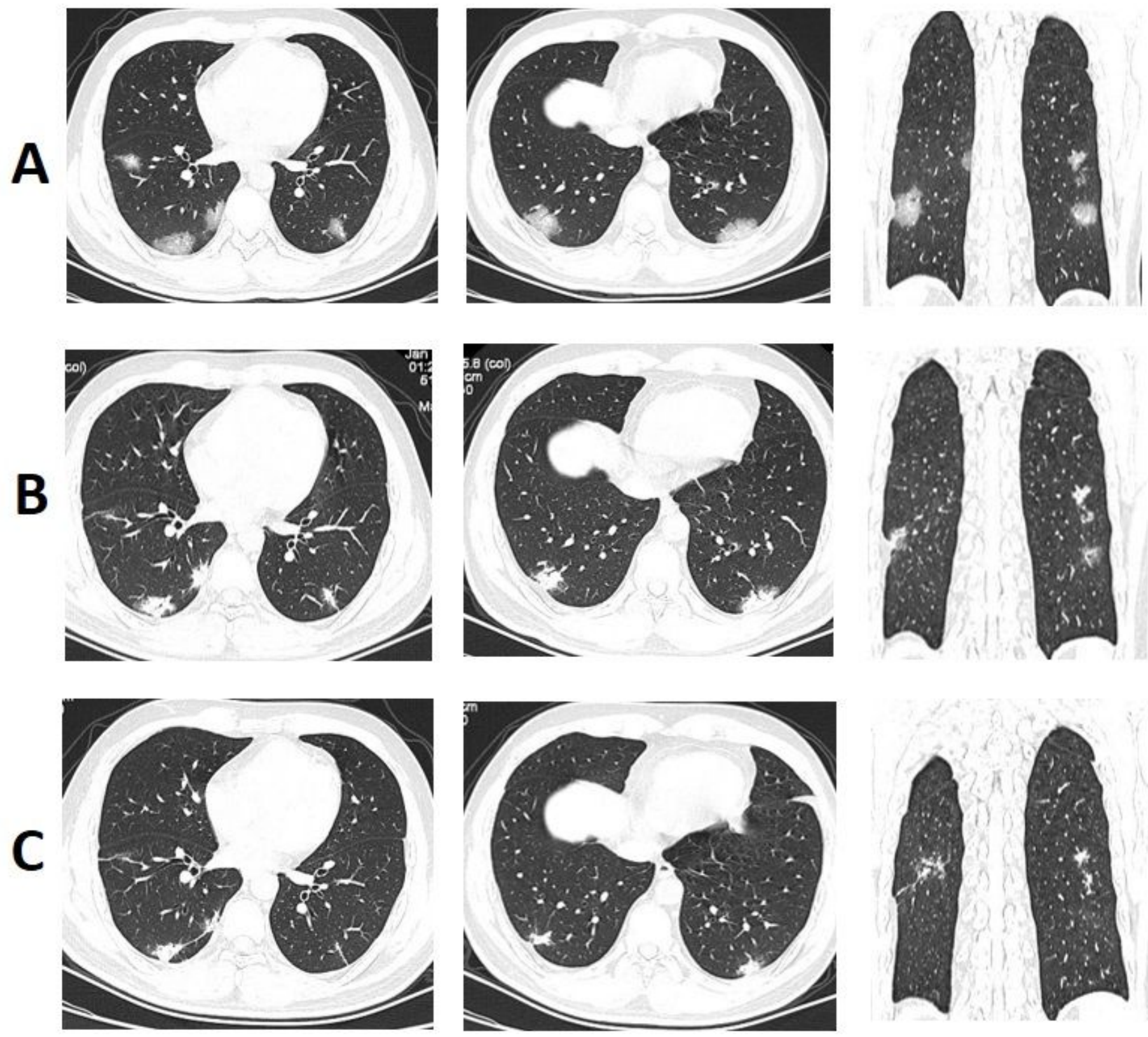

Figure 2

The temporal changes of laboratory outcomes for COVID-19 patients on the day 1 to day 7 and the last day of hospitalization. Created by R software, version 3.6.0. 